\title{
Research on Foreign Direct Investment in Service Industry
}

\author{
Li Kun ${ }^{1, a^{*}}$ \\ ${ }^{1}$ Shaanxi Normal University, Xi'an, China
}

\begin{abstract}
Under the national policy goal of increasing labor income and increasing employment rate, the service industry is expected to be a powerful engine for stimulating economic growth, optimizing industrial structure and absorbing employment, while foreign direct investment is playing an important role in promoting industrial upgrading and improving efficiency. This article first analyzes the trade effects of multinational companies in the service industry based on monopolistic advantage theory, product life cycle theory, internalization theory and the eclectic paradigm of international production, and then introduces the development status of foreign direct investment in China's service industry. The study found that under the premise of ensuring the national economy and social security, corresponding policies should be adopted in the introduction of investment in specific industries to correctly guide the flow of foreign capital so that it can serve to optimize the industrial structure of the service industry.
\end{abstract}

\section{Theories of foreign direct investment in service industry}

\subsection{Monopolistic Advantage Theory}

The theory believes that the incomplete domestic and foreign markets make multinational companies with monopoly advantage obtain high monopoly profits, so monopoly advantage is also regarded as a prerequisite for multinational companies to make direct investment. These advantages include: controlling a certain specialized technology, monopolizing the source of raw materials, mastering a good sales channel and sales network, strong product research and development capabilities.

The Monopolistic Advantage Theory also has a strong explanatory power in FDI in the service industry. In the traditional service industry represented by the retail industry, the global marketing network and marketing experience are the monopoly advantages of multinational companies in foreign direct investment.

\subsection{Product Life Cycle Theory}

Vernon divides the product cycle into three stages: innovation, maturity and standardization. He believes that within the scope of the international market, the product life cycle determines the company's foreign direct investment decision, and pointed out that in the mature stage, companies will make foreign direct investment. However, with the acceleration of the globalization process of the world market and the great advancement of technology, the demand or preference for products between developed countries and developing countries has converged, and product life cycles have been shortened sharply. It is difficult for the eliminated products of developed countries to form a great demand in developing countries, and the explanation of the product life cycle for the direct investment of multinational companies has gradually weakened.

\subsection{Internalization Advantage Theory}

The theory believes that the activities outside the production of multinational companies, such as research and development, training, are closely related to intermediate products (semi-finished products and raw materials, combined with various knowledge in patent rights and human capital). The incompleteness of the intermediate product market, especially the knowledge product market, prevents enterprises from effectively using the external market to coordinate their business activities, which constitutes a key prerequisite for internalization. When the process of internalization transcends national boundaries, multinational companies emerge. International direct investment by multinational companies is to avoid high transaction costs caused by transaction uncertainty.

The direct investment by multinational companies in "intangible" intermediate products is classified as service FDI. The low cost efficiency of intangible intermediate products and the uncertainty of buyers in service consumption will lead to an increase in transaction costs, thereby making it possible for multinational companies to make direct investment. Therefore, internalization theory can be used to explain the motivation of FDI investment in the service industry. 


\subsection{The Eclectic Paradigm of International Production}

$\mathrm{J} \cdot \mathrm{H} \cdot$ Dunning believes that multinational companies must have three advantages for foreign direct investment, namely, ownership advantage, internalization advantage and location advantage. The relationship between these three advantages and external expansion is shown in Table 1:

Table1. List of overseas expansion methods of multinational companies

\begin{tabular}{|l|l|l|l|l|}
\hline Advantages & $\begin{array}{l}\text { Whether it have this } \\
\text { advantage }\end{array}$ & $\begin{array}{l}\text { Overseas } \\
\text { expansion } \\
\text { mode }\end{array}$ \\
\hline $\begin{array}{l}\text { Ownership } \\
\text { advantage }\end{array}$ & $\checkmark$ & $\times$ & $\times$ & $\begin{array}{l}\text { Technology } \\
\text { transfer }\end{array}$ \\
\hline $\begin{array}{l}\text { Internalization } \\
\text { advantage }\end{array}$ & $\checkmark$ & $\checkmark$ & $\times$ & $\begin{array}{l}\text { Technology } \\
\text { transfer or } \\
\text { export }\end{array}$ \\
\hline $\begin{array}{l}\text { Location } \\
\text { advantage }\end{array}$ & $\checkmark$ & $\checkmark$ & $\checkmark$ & $\begin{array}{l}\text { Direct } \\
\text { investment }\end{array}$ \\
\hline
\end{tabular}

In the modern service industry, having the ability to quickly grasp technology and information can enable enterprises to effectively protect their intangible assets and core competitive advantages. In addition, the ownership advantages of service companies in many aspects such as human resources, knowledge, innovation, finance, data processing, access factors, and market entry capabilities are all applicable to the analysis of the ownership advantages of service industry multinational companies in direct investment.

The advantages of internalization here are similar to those emphasized by internalization theory. They are also to overcome the incompleteness and uncertainty of the external market, protect their proprietary intellectual property rights from infringement, effectively reduce transaction costs, and ensure the quality Internal standardization and differences with other similar products, bypassing various barriers set by the host country government.

Location advantage mainly refers to the unique advantages of the host country. It is the element endowment that the host country cannot or is not easy to move, and the advantage formed by the existence of specific conditions such as the host country's policies and regulations. Obtaining and maintaining location advantages is the key to direct investment by multinational companies in the service industry. For the service industry, the definition of location advantages varies from industry to industry. Generally speaking, the location advantages considered by multinational companies in the service industry include population quality, market scale, economic situation, cultural environment, policies and regulations.

\section{Trade effects of multinational companies in service industry}

\subsection{Interactive sequence of FDI and trade in services}

The international development of manufacturing multinational companies is characterized by a linear sequence, that is, from trade to investment, or investment to trade. Linear order is a typical feature of the internationalization of manufacturing enterprises, whether large or small, and whether they are from developed or developing countries. Compared with the manufacturing industry, due to the particularity of the service industry, many service products cannot meet the needs of the international market through trade, and must be directly produced locally. In addition, out of the need to follow customers, the internationalization of multinational companies in the service industry is achieved through investment first. Therefore, service companies do not fully refer to the gradual linear trade and investment approach adopted by manufacturing multinational companies to conduct multinational operations. This is the main reason why the proportion of FDI in the service industry has increased in the past 30 years. With technological progress and the gradual tradability of services, the trade activities of multinational companies in the service industry have increased, especially with the advancement of information and communication technology, and the scale of crossborder provision of information services has increased. Technological progress has not only increased the tradability of services, but at the same time, in order to seek lower labor costs, more skilled functions and strategic resources, more multinational companies in the service industry have also begun to invest overseas. Therefore, according to the definition of commercial existence as service trade, the internationalization of multinational companies in the service industry presents an interactive internationalization sequence.

\subsection{The factors of FDI trade creation effect in service industry}

In addition to the service industry's own characteristics that determine the FDI in the service industry before trade and the interactive internationalization sequence between the two, according to the eclectic theory of international production, the location advantage and ownership advantage of the host country determine the trade behavior.

\subsubsection{The factor of host country}

First of all, due to the development of information and communication technology and Internet technology, the openness of the service industry in various countries has continued to increase, which has reduced trade barriers and reduced investment costs. For example, developing countries continue to open up core industries such as transportation and communications, and privatize stateowned enterprises' control industries. Therefore, multinational companies in the service industry have 
accelerated their global expansion. In particular, efficiency seeks the promotion of multinational companies in the service industry. Trade activities between parent and subsidiary companies and branches are frequent. Secondly, the coherence of the host country system will help service multinational companies continue to conduct business in the host country, improve the vertical efficiency of life, and form a trade creation mechanism. In addition, the degree of multinational operations of service multinational companies in the host country, including scale, product structure, R\&D investment, advertising, international production experience, and FDI scale, will affect the scale of internal trade of service multinational companies and the proportion of internal trade in the entire trade. Third, the degree of regional economic integration will also affect the scale and pattern of internal trade of service multinational companies. The higher the degree of regional economic integration, the finer the professional division of labor among multinational companies in the service industry and the larger the scale of internal trade.

\subsubsection{The factor of internalization}

According to the theory of multinational corporations, the selection of FDI by multinational corporations in the service industry is mainly based on the balance of costs and benefits and the incompleteness of the market. First, there is the trade-off of transaction costs. According to the existence of transaction costs proposed by Coase, companies will choose FDI to achieve cross-border trade through transactions between affiliated institutions. For multinational companies in the service industry, the generation of their internal trade is also the result of enterprises achieving economies of scale and scope through integration. Second, the reputation of the service is especially important. Since service multinational companies cannot directly observe certain actions that foreign managers are taking, and the cost of controlling these activities is high, they cannot control the quality of services. Multinational companies in the service industry tend to internalize production through FDI, which reduces costs on the one hand, and guarantees the quality of services on the other, forming the trade creation effect of FDI and realizing the scale effect of FDI in the service industry.

\subsection{FDI productivity spillover effects in the service industry}

Based on the needs of development, host countries will generally direct FDI to industries where the country does not have a comparative advantage. The entry of multinational companies in the service industry will effectively increase competition in these industries and increase labor output per unit of resource. For example, Singapore proposed the International Trader Program, which aims to attract more multinational companies in the trade service industry to settle in and stabilize Singapore's status as an international trade center. Since multinational corporations have higher productivity than domestic enterprises, the agglomeration of multinational corporations in the service industry can increase the productivity of the host country's industry, and by eliminating low-efficiency domestic enterprises, the average productivity of the domestic industry can be increased. In addition, multinational companies in the service industry can also have spillover effects on domestic service companies and increase the productivity of domestic companies. For example, when retail giants such as Wal-Mart and Carrefour enter the host country, they will generally require local suppliers to improve production processes in accordance with their management systems. Suppliers that cannot meet the requirements will lose market share or be eliminated, and the productivity of the winning companies will be effectively improved. Service multinational corporations also improve the productivity of host country enterprises through technology spillover effects. For example, the labor mobility of service multinational corporations exerts spillover effects on local enterprises. Multinational companies in the service industry can also exert technology spillover effects on local enterprises through franchising, especially in industries with obvious knowledge spillover characteristics such as information, software, and finance.

\section{The development of service industry FDI in China}

With the accelerated deployment of multinational service companies in China, the use of foreign direct investment in China's service industry has developed rapidly, especially after China joined the WTO in 2001. In 1997, the actual utilization of foreign investment in the service industry was US\$12.06 billion, and by 2013 it reached US\$65.85 billion, an increase of four times.

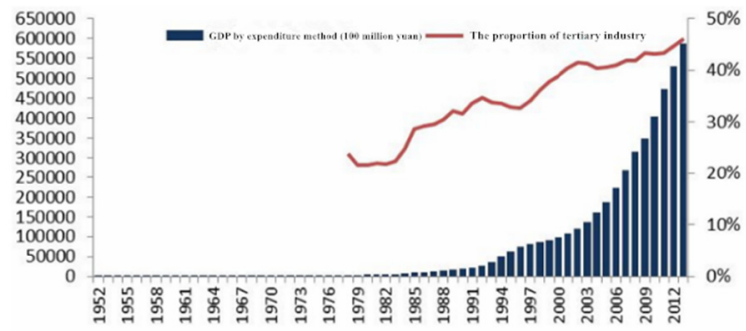

Fig 1. China's economic development and the proportion of service industry

With the deepening of the use of foreign capital in the service industry, multinational companies in the service industry have also accelerated their pace of entering the Chinese service industry market, which will have a profound impact on China's future service industry development. In terms of total volume, FDI in China's service industry has increased year by year, and relatively large progress has been made. 


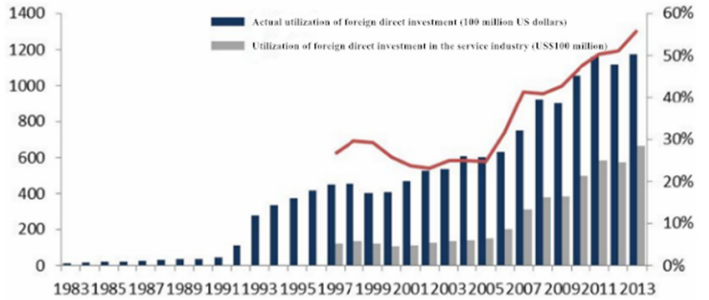

Fig 2. China's actual utilization of foreign investment

In recent years, the growth of direct investment attracted by China's service industry has been relatively stable, and China's service industry has formed a relatively open pattern. Foreign investment in finance and insurance, transportation, communications, tourism, retail, catering, advertising, professional consulting, education, healthcare, and trade, Computer and related services, construction, real estate and other service sectors are playing an active role. The industry in which multinational service companies are located has gradually diversified from the initial tourism facilities, real estate, and accommodation and catering industries.

\section{Suggestions on attracting investment in China's service industry}

At present, there is duality in the implementation of policies to guide investment in the service industry. On the one hand, the particularity of the service industry involves the country's economy and social security and requires careful opening up; on the other hand, policy objectives are divided and investment supervision is weak. Regarding the issue of opening up the service industry, China needs to actively, steadily and orderly expand the opening up of the service industry in accordance with the actual situation of its own development and the principles of "gradual" and "managed". At the same time, investment liberalization and the global development of investment promotion have also accelerated the pace of opening up of China's service industry. As for the problem of inadequate supervision in attracting capital in the service industry, it can be reasonably resolved in the process of institutionalization and legalization. In particular, the supervision of the service industry, which is related to the security of the national economy, must be implemented. Relevant legal constraints and punishment standards must be followed up. The formulation and implementation of industry standards should strive to improve, and strive to achieve interlocking links in all aspects of attracting capital in the service industry. At the same time, attention should be paid to the integration of domestic and international laws.

Further scientifically and rationally expand the opening up of the service industry, broaden the scope of investment in the service industry, and appropriately relax entry conditions. In attracting capital in specific industries, it is necessary to correctly guide the flow of foreign capital so that it serves to optimize the industrial structure of the service industry. For industries related to the country's political, economic, social, cultural and ecological safety, foreign investment must be strictly restricted, such as air traffic control, compulsory education, social surveys, the construction and operation of nature reserves and internationally important wetlands; Restrictive measures should be taken in the field, such as railways, road transport companies, banks, insurance companies, securities companies; and for high-tech industries that are conducive to the development of the national economy and people's livelihood, measures should be actively taken to promote foreign investment, combined with foreign investment entry models, and prioritized guidance Foreign capital enters in the form of joint ventures and cooperation, thereby enhancing the safety supervision and spillover effects of foreign investment. Therefore, China should encourage foreign capital to enter modern, cutting-edge, high-tech, and domestic immature industries in attracting investment in the service industry, so as to absorb technological spillovers and give play to late-mover advantages. However, certain protective policies are still needed in basic key industries.

\section{Conclusions}

This article provides a certain reference value for the service industry to effectively utilize foreign capital in order to achieve the strategic goals of expanding domestic demand, increasing employment, and promoting economic growth. The study found that China's service industry has developed rapidly by using foreign direct investment, and the industry in which service multinational companies are located has gradually diversified.

\section{Acknowledgments}

Thank you for your hard work and guidance from the teachers of the International Business School of Shaanxi Normal University. Thank you for your tirelessly imparting knowledge to us.

\section{References}

1. Diao Fujuan. Study on the development effect of China's foreign direct investment in service trade. Economic Science Press, Beijing.

2. Zheng Jichang. Service Economy Theory. China Business Press, Beijing.

3. Zhao Wei. Theory, Policy and Realistic Issues of International Trade (Second Edition). Dongbei University of Finance and Economics Press, Dalian.

4. Pan Yingli. Theoretical Research on Effective Utilization of Foreign Capital. East China Normal University Press, Shanghai. 